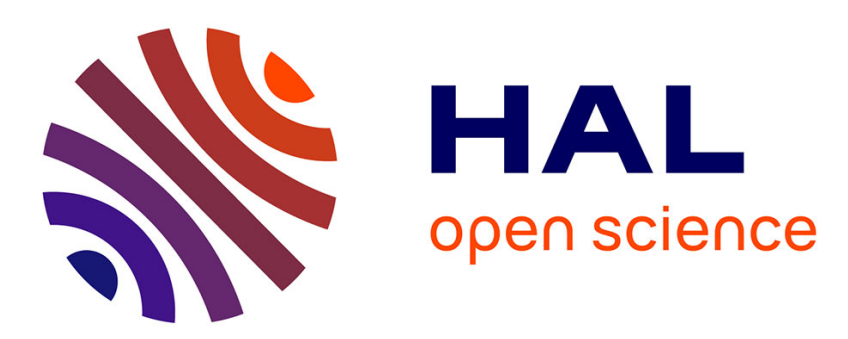

\title{
Contribution of meandering rivers to natural carbon fluxes: Evidence from the Ucayali River, Peruvian Amazonia
}

Romain Walcker, Dov Corenblit, Frederic Julien, Jean-Michel Martinez, Johannes Steiger

\section{To cite this version:}

Romain Walcker, Dov Corenblit, Frederic Julien, Jean-Michel Martinez, Johannes Steiger. Contribution of meandering rivers to natural carbon fluxes: Evidence from the Ucayali River, Peruvian Amazonia. Science of the Total Environment, 2021, 776, pp.146056. 10.1016/j.scitotenv.2021.146056 . hal-03162177

\section{HAL Id: hal-03162177 \\ https://hal.uca.fr/hal-03162177}

Submitted on 8 Mar 2021

HAL is a multi-disciplinary open access archive for the deposit and dissemination of scientific research documents, whether they are published or not. The documents may come from teaching and research institutions in France or abroad, or from public or private research centers.
L'archive ouverte pluridisciplinaire HAL, est destinée au dépôt et à la diffusion de documents scientifiques de niveau recherche, publiés ou non, émanant des établissements d'enseignement et de recherche français ou étrangers, des laboratoires publics ou privés. 


\section{River, Peruvian Amazonia}

3 Romain Walcker ${ }^{1}$, Dov Corenblit ${ }^{2}$, Frédéric Julien ${ }^{1}$, Jean-Michel Martinez ${ }^{3}$, Johannes Steiger ${ }^{2}$

$4{ }^{1}$ Laboratoire Ecologie Fonctionnelle et Environnement, Université de Toulouse, CNRS,

5 Toulouse, France.

$6 \quad{ }^{2}$ Université Clermont Auvergne, CNRS, GEOLAB, 63000 Clermont-Ferrand, France

$7 \quad{ }^{3}$ GET, Institut de Recherche pour le Développement, CNRS, Toulouse, France.

8 *Corresponding author:

9 Romain Walcker, Porte 336, Bât. 4R1, Université de Toulouse, 118 route de Narbonne 31062,

10 Toulouse, France.

11 Phone: +33-(0)5-61-55-89-27.

12 Fax: +33-(0)5-61-55-89-01.

13 E-mail: romain.walcker@univ-tlse3.fr

14 Journal: Science of the Total Environment

15 Paper type: Full papers

16 Keywords: Amazon; carbon; floodplain; forest age; meandering river; remote sensing; 


\section{Abstract}

Better understanding the fate of the atmospheric carbon (C) captured by plant photosynthesis is essential to improve natural C flux modelling. Soils are considered as the major terrestrial bioreactor and repository of plant $\mathrm{C}$, whereas channel networks of floodplain rivers collect and transport, throughout the aquatic continuum, a significant part of plant primary production until its export through outgassing or sequestration in marine sediments. Here, we show that river meandering in forested floodplains is a crucial and widely overlooked Earth surface process promoting $\mathrm{C}$ fluxes from the atmosphere to the aquatic continuum, via the floodplain vegetation. Over a recent period of 35 years (1984-2019), we quantified those C fluxes in one of the most active meandering rivers on Earth, the Ucayali River, Peru, South America. We used map time series combined with above-ground forest $\mathrm{C}$ data to derive the amount of $\mathrm{C}$ that is annually captured by the growing floodplain vegetation within the active meander belt, as well as exported to the aquatic continuum by lateral channel erosion. We found that the annual building and erosion of forested floodplain areas was nearly balanced over time with 19.0 $\pm 7.7 \times 10^{3} \mathrm{ha}^{-1} \mathrm{yr}^{-1}$ and $19.8 \pm 6.7 \times 10^{3} \mathrm{ha}^{-1} \mathrm{yr}^{-1}$, respectively. While growing forests within

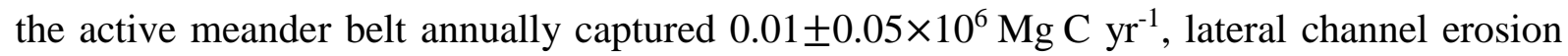
provided the nearly 100 -fold amount of $\mathrm{C}$ to the river channel and its streamflow, i.e.

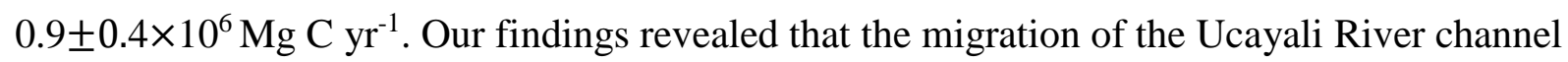
provided nearly 10-times more lignified C per unit area to the aquatic continuum $(44.7 \pm 21.4$ Mg C ha-1 $\mathrm{yr}^{-1}$ ) than non-meandering central Amazonian floodplains do. Together, these findings point to the importance of quantifying the overall contribution of meandering rivers to natural C fluxes worldwide. 


\section{Introduction}

Floodplains are areas of high primary production which provide fresh autochthonous carbon (C) to river waters through litterfall, plant and micro-organism respiration (Abril et al., 2014). Levels of plant production in floodplains and the extent of the floodplain area can therefore considerably modulate the overall C quantity found in river waters (Ward et al., 2017). Hence, floodplain vegetation, algae and floating macrophytes in highly productive and preserved tropical areas, directly and rapidly provide organic and inorganic C to rivers (Abril et al., 2014; Sawakuchi et al., 2017). Abril et al. (2014) further suggested that central Amazonian wetlands export half of their gross primary production to rivers, being the primary sources for $\mathrm{CO}_{2}$ outgassing by the Amazon.

Over the last decade, several studies successively updated regional and global estimates of river C fluxes from land to oceans (Drake et al., 2018). These studies underscored large data gaps and uncertainties, suggesting that $\mathrm{C}$ fluxes might be much larger than previously thought. In particular, uncertainties in the contribution of wetlands and macrophytes as a source of $C$ for rivers has been highlighted (Spencer et al., 2013) and the need for new investigations identified. Furthermore, river meandering, among other processes contributing to $\mathrm{C}$ input into rivers, river meandering remains however a largely overlooked Earth surface process (Peixoto et al., 2009). Yet, this process is recognized in sculpting the Earth surface since more than 5 centuries, and studies have recently pointed out its potential role in biogeochemical fluxes (Iepli \& Lapôtre, 2019). Abiotic factors, like sedimentary dynamics in meandering rivers, have been suggested as essential than biotic factors, like productivity and respiration, in the terrestrial organic $\mathrm{C}$ cycle (Torres et al., 2017; Ielpi \& Lapôtre, 2019).

Typically, meandering rivers are characterized by lateral bank erosion occurring at the outer meander bends, whereas lateral accretion processes form point bars within inner meander bends (Leopold and Wolman, 1960; Allen, 1965). Within the Amazon basin, lateral channel migration 
generates meander scrolls forming a sequence of ridges and swales, on which a sequential primary forest succession of high productivity rapidly takes place (Salo et al., 1986; Junk et al., 1989; Puhakka et al., 1992). Forest succession, leading eventually to the mature stage, continues when the channel further migrates and point bars are integrated into the floodplain. Conversely, channel migration also causes bank erosion which in turn promotes direct massive inputs of coarse woody material to river channels, thus providing substantial quantities of autochthonous C, potentially exceeding those imported through litterfall and respiration. Active river meandering closely linked to point bar formation, floodplain aging and lateral channel erosion, thus presents a relevant Earth surface process to consider for accurately quantifying and understanding floodplain $\mathrm{C}$ sequestration and its export to the aquatic continuum (Wohl et al., 2013; Sutfin et al., 2016).

Here, we aimed to provide evidence that river meandering in Amazonian floodplains significantly contributes to river $\mathrm{C}$ budgets. Our objective was to quantify the amount of $\mathrm{C}$ that annually accumulates in the forest biomass, as well as the part that is annually exported to the river channel, within the active meander belt of the river, i.e. the area where contemporary channel migration occurred. We investigated one of the major active tributaries of the Amazon, the Ucayali River, Peru, over a period of 35 years (1984-2019). We used the yearly water classification history dataset provided by the Joint Research Centre to produce annual maps of point bar formation, floodplain ages and river channel erosion in the 1984-2019 active meander belt. Annual maps were combined with a model predicting the living above-ground forest $\mathrm{C}$ stock from the floodplain age to derive amounts of $\mathrm{C}$ annually fixed by net primary production and exported to river waters after bank erosion. The quantity, quality and fate of the C provided by Amazonian meandering rivers to the aquatic continuum is discussed in respect to the existing literature.

\section{Method}


The Ucayali River is located in the western part of the Amazon basin (Fig. 1a). It is a major tributary of the Amazon River extending approximately $900 \mathrm{~km}$ from its upstream confluence with the Rio Tambo and Rio Urubamba to its downstream confluence with the Marañón River. The mean annual water discharge is about $12100 \mathrm{~m}^{3} \mathrm{~s}^{-1}$ and water depth between low and high flood flows can range from 8 to $15 \mathrm{~m}$ (Santini et al., 2019). The maximum and minimum monthly flows, recorded over the 1996-2018 period at the Requena gauging station, is of 22900 and $2500 \mathrm{~m}^{3} \mathrm{~s}^{-1}$ respectively (HYBAM, 2020). Close to the town of Pucallpa, the floodplain width is about $25 \mathrm{~km}$ and the active meander belt is approximately $10 \mathrm{~km}$ in width (Fig. 1b, c). The Ucayali is considered as one of the last pristine free meandering white-water rivers worldwide, characterized by high suspended sediment loads, nutrient-rich waters and high lateral channel migration rates within an unconstrained, forested floodplain (Constantine et al., 2014). Within meandering floodplain rivers, forest primary succession is distinctly age-zonated (Salo et al., 1986; Junk et al., 1989; Puhakka et al., 1992). The vegetation succession progresses from early successional stages dominated by short-lived species to latter successional stages dominated by long-lived species along a cross-river and age gradient (Salo et al., 1986; Lamotte, 1990; Fig. 2). The early stage of primary succession begins on newly formed alluvial bars, mainly point bars, rapidly colonized by Tessaria integrifolia L. and Gynerium sagittatum, forming dense canopies of about 5-8 $\mathrm{m}$ in height. This early pioneer stage is replaced by a second stage dominated by Cecropia tessmannii, forming a closed canopy of about 14-18 m in height. The Cecropia forest is located on older meander scrolls in backwater depressions. During these two first stages, vegetation contributes to sediment and organic matter trapping, which leads to floodplain construction and soil C sequestration (Fig. 2; Salo et al., 1986). The following stage is a mixed forest dominated by Ficus insipida and Cedrela odorata, forming a closed canopy of about 20-25 m in height. At this stage, floodplain surface elevation is about 5 
m above the low water level. Its topography is more homogeneous compared to the pioneer

117 zone in the previous stages of succession. This is due to the deposition of large amounts of silt 118 in backwater depressions during seasonal flooding. The later successional mixed forest is more diversified and composed of large trees with a canopy of about $40 \mathrm{~m}$ in height. Soil topography 120 of the floodplain at this level (> 5-10 m above the low water level) is generally flat with only 121 minor remaining depressions. This forest succession trajectory is basically the same at each meander of the Ucayali River (Kalliola et al., 1991). Lateral channel erosion leads to a continuous reset and regeneration of the primary vegetation succession over large areas (Salo et al., 1986; Kalliola et al., 1991). Since point bars of the Ucayali River are either rapidly eroded or integrated into the forested floodplain during lateral channel migration, we will, hereafter, 126 exclusively distinguish the river channel from its floodplain, including point bars.

We used the yearly water classification history dataset (v1.2) provided by the Joint Research

129 Centre (JRC) and freely available on the Google Earth Engine (GEE) platform (Gorelick et al., 2017). This dataset was firstly created by Pekel et al. (2016) and now consists in 36 annual raster maps spanning the 1984-2019 period. Pixels size approximately $900 \mathrm{~m}^{2}$ at ground level

132 and are classified in 'no data', 'non-water', 'seasonal water' or 'permanent water' (Fig. S1 in 133 Appendix A). In order to create an envelope for data extraction, we firstly downloaded geometries (i.e. polylines shapefiles) of the Ucayali River from the Open Street Map database available at https://download.geofabrik.de. Then, we created a 10-km buffer across the river using the ArcGIS software package (ESRI, Redland, USA). The yearly water classification

137 history dataset overlaying the river buffer was finally downloaded from the GEE platform.

138 Using the MatLab software package (Mathworks, Natick, USA), the 36 annual raster maps were 139 proceeded in order to map annual areas of floodplain formation, ages and erosion. The 
140 algorithm was applied pixel-by-pixel and year-by-year as illustrated in Figure 3. Pixels that

141 were classified as 'seasonal water' or 'permanent water' at a given year (e.g. 1984; Fig. 3a),

142 and classified 'non-water' the following year (e.g. 1985), were mapped as 1-year-old pixels.

143 Each year from 1985 to 2019, every pixel age-determined at a given year (e.g. 1-year-old in 144 1985) and remaining 'non-water' the following year (e.g. 1986) was incremented with one 145 additional year (e.g. 2-year-old in 1986). Remaining 'non-water' and 'no data' pixels with no 146 age between successive years (e.g. between 1984 and 1985) were set to age 'non-determined' 147 (ND). Typically, ND pixels corresponded to floodplain and upland areas created before 1984.

148 Each year, from 1985 to 2019, every pixel age-determined at a given year (e.g. 2-year-old in 149 1986) and classified 'seasonal water' or 'permanent water' the following year (e.g. 1987) was 150 considered as an eroded area (Fig. 3b) and reset to age 0 (e.g. 0-year-old in 1987).

\subsection{Deriving C-stocks from floodplain ages}

In line with Pahukka et al. (1992), we assumed that on the Ucayali River, pioneer vegetation colonizes bare alluvial bars from the year of their creation (Fig. S2 in Appendix A). We thus considered that the vegetation age is equal to the floodplain age. We used published data to predict the forest above-ground carbon stock (C-stock in $\mathrm{Mg} \mathrm{C} \mathrm{ha}^{-1}$ ) from the floodplain age (age in years), and constructed a model predicting C-stock as a function of age (Fig. 3c). The data were published by Schöngart and Wittmann (2010) and based upon thousands of in situ vegetation structure inventories and tree ring measurements within floodplains of central Amazonia. Forest above-ground carbon stocks were estimated in several, almost undisturbed successional stages, with stands varying between 7 and 240 years of age. Forest structure data

161 and several allometric models were used to construct a data series of C-stocks per forest age.

162 First, we extracted data from the figure 18.10 presented by Schöngart and Wittmann (2010)

163 using Web Plot Digitizer 4.3 software (Ankit Rohatgi, Pacifica, California, USA). Second, we 
164 fitted a $3^{\text {rd }}$ order polynomial model to the 35 first years of the data series. These 35 years

165 corresponded to the forest establishment that we analysed on the Ucayali River between 1984 166 and 2019. For floodplain forests established before 1984 (ND ages; Fig. 3a, b), we assumed a

167

168

169

170

171

172

173

174

175

176

177

178

179

180

181

182

3.4.Annual accumulation of floodplain forest C-stocks and its erosion

Floodplain areas were converted into above-ground forest C-stocks based on our model (Fig. 3c). The annual total C-stock (in $\mathrm{Mg} \mathrm{C} \mathrm{ha}^{-1}$ ) was obtained by summing C-stocks of all vegetated floodplain ages since 1984. An annual C accumulation rate was obtained by (1) subtracting the total C-stock of year $n$ by the one of year $n-1$, and (2) by applying a linear regression and the calculation of the root mean square error (RMSE). C-accumulation in floodplain and upland forest areas established before 1984 were not considered in the present study because they were outside of the 1984-2019 active-meander belt. Annual C-stock lost through floodplain erosion was obtained by summing eroded C-stocks of determined and non-determined (ND) floodplain ages.

\section{Results}

4.1.Annual vegetated floodplain area formation and erosion

Over the 1984-2019 period, the water surface area of the Ucayali River accounted for $220 \pm 25$ $\times 10^{3}$ ha (annual average and its standard deviation; Appendix B). Maximum water surface area extensions were observed in 1988, 1994, 2001, 2011, 2017 and minimums in 1987, 1992, 1997, 2005, 2010, 2013 and 2018 (Fig. 4a). Negative anomalies appeared mainly before 2000 and positives anomalies mainly after 2000. Yearly formation of floodplain areas occurred mainly 
within inner meander bends and accounted in average for $19.0 \pm 7.7 \times 10^{3} \mathrm{ha}^{-1} \mathrm{yr}^{-1}$ (Fig. 4b; Fig. 5; Appendix B and C). Conversely, floodplain erosion was located mainly in outer meander bends and closely balanced floodplain formation with an average of $19.8 \pm 6.7 \times 10^{3} \mathrm{ha}^{-1} \mathrm{yr}^{-1}$ (Fig. 4c; Appendix B and C).

\subsection{Age structure of vegetated floodplain areas}

We found that meandering promotes rejuvenation and recurrent formation of large areas of bare alluvial bars that are quickly colonized by pioneer vegetation. Over the 1984-2019 period, ages of floodplain areas were unevenly distributed (Fig. 6a). One-year-old floodplain areas largely dominated. However, about $1 / 3$ of these newly formed floodplain areas were eroded the following year. Indeed, we found that older age classes generally decreased in areas following a negative logarithmic trend (Fig. 6a). This trend resulted from floodplain erosion (Fig. 6b). Newly established floodplain areas at inner meander bends were primarily affected by erosion at a rate of $6.4 \pm 3.3 \times 10^{3} \mathrm{ha}^{-1} \mathrm{yr}^{-1}$, i.e. $1 / 3$ of the yearly formed floodplain surface area $\left(19.0 \pm 7.7 \times 10^{3} \mathrm{ha}^{-1} \mathrm{yr}^{-1}\right)$. The rate of erosion decreased from younger to older floodplain areas (Fig. 6b). Floodplain erosion occurred equally in outer meander bends and in areas established before 1984, i.e. non-determined in age (ND) in the present study. Erosion in areas of ND ages accounted annually for about $7.0 \pm 3.8 \times 10^{3} \mathrm{ha}^{-1} \mathrm{yr}^{-1}$ (Fig. 6b; ND).

\subsection{Annual changes in floodplain forest C-stocks}

Our model used to derive C-stocks from floodplain ages showed a very good adjustment to the data ( $\mathrm{R}^{2}=0.99$; Fig. 7). One-year-old vegetation accounted for an average of $0.7 \mathrm{Mg} \mathrm{C} \mathrm{ha}^{-1}$ and increased to 95.3 $\mathrm{Mg} \mathrm{C} \mathrm{ha-1}$ at 35-year-old. Old-growth floodplain forests, i.e. those that established on areas older than 70-year-old, levelled off at nearly $115 \mathrm{Mg} \mathrm{C}^{-1}$ (Fig. 7). We combined annual maps of floodplain ages with our C-stock model and produced annual maps of above-ground C-stocks (Fig. 8). The mean annual C accumulation rate of floodplain forests 
established after 1984 in the Ucayali 1984-2019 active meander belt was estimated at $0.01 \times 10^{6}$

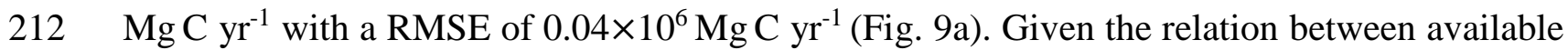

213 floodplain area and C-stock, the generation with the most effective C-sequestration capacity 214 was the 23-year-old forest (Fig. 9b). Annual floodplain erosion caused by lateral channel

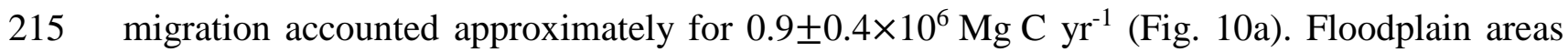
216 which established before 1984 largely dominated eroded C-stocks with $0.8 \pm 0.4 \times 10^{6} \mathrm{Mg} \mathrm{C}^{-}$ $217{ }^{1}$ (ND; Fig. 10b).

\section{Discussion}

5.1. Annual floodplain formation balances annual floodplain erosion in area but not in $\mathrm{C}$ budget

We found that rates of annual floodplain formation and rates of annual floodplain erosion appeared to be in balance over time with $19.0 \pm 7.7 \times 10^{3} \mathrm{ha}^{-1} \mathrm{yr}^{-1}$ and $19.8 \pm 6.7 \times 10^{3} \mathrm{ha}^{-1} \mathrm{yr}^{-1}$, respectively. Our results confirm those reported by Puhakka et al. (1992) who showed that outer banks and point bars have, respectively, roughly equivalent rates of erosion and sediment deposition, maintaining a relatively constant channel width. Similarly, Peixoto et al. (2009) and Schwenk et al. (2017) reported an annual balance of erosion and deposition over large study areas and multidecadal periods. Peixoto et al. (2009) suggested that annual release of C caused by river dynamics would be much higher than the $\mathrm{C}$ annually sequestrated within the floodplain. Our results have quantitatively confirmed their hypothesis. Indeed, within the 1984-2019 active meander belt of the Ucayali River, the floodplain forest annually accumulates $0.01 \pm 0.04 \times 10^{6}$ $\mathrm{Mg} \mathrm{C} \mathrm{yr}^{-1}$ and exports $0.9 \pm 0.4 \times 10^{6} \mathrm{Mg} \mathrm{C} \mathrm{yr}^{-1}$. Although it appeared that there is a balance in areas between floodplain formation and erosion, we show that there is however a strong imbalance in rates of floodplain forest $C$ fixation and export to river waters caused by lateral 
channel migration. This imbalance is mainly due to massive erosion of old-growth floodplain forests with high C-stock densities (about $115 \mathrm{Mg} \mathrm{C} \mathrm{ha}^{-1}$ ).

\subsection{Lateral channel migration as a significant $\mathrm{C}$ provider to the aquatic continuum}

There are multiple $\mathrm{C}$ sources for the aquatic continuum, i.e. between aquatic ecosystems from the atmosphere, headwater streams and inland waters, to coastal and marine systems. First, the C conveyed to streams and rivers can be provided during precipitation where water drops can be enriched in dissolved and particulate organic C (DOC, POC; Ward et al., 2017). Then, when entering forest canopies, drops capture DOC and POC at the surface of leaves, branches and trunks. By instance, in the Rio Negro region, throughfall fluxes of $27.5 \mathrm{~kg} \mathrm{C} \mathrm{ha}^{-1} \mathrm{yr}^{-1}$ have been reported (Filoso et al., 1999). Throughfall fluxes that range between 68.4 and $195.1 \mathrm{~kg} \mathrm{C} \mathrm{ha-1}$ $\mathrm{yr}^{-1}$ and stem flow fluxes of $1.5 \mathrm{~kg} \mathrm{ha}^{-1} \mathrm{yr}^{-1}$ have been also reported in Amazonia (Neu et al., 2016). In addition to the $C$ provided by rainfall, root and canopy litterfall and respiration in floodplain forests together with algal and floating macrophyte communities are considered as the main C pathways to the aquatic continuum (Ward et al., 2017).

Even though they represent only about $14 \%$ of the Amazon basin, floodplains are highly productive compared to terrestrial uplands and are hydrologically connected to river channels during yearly overbank flooding (Richey et al., 1980; Junk, 1985; Hoffmann et al., 2009). It has been reported that in Central Amazonia, floodplains can provide an amount of 59.6 \pm 38.7 Mg C ha-1 $\mathrm{yr}^{-1}$ to the channel network and streamflow (Abril et al., 2014). Here, we point out that lateral channel erosion is a crucial and overlooked physical driver delivering large amounts of $\mathrm{C}$ to rivers. We show that channel migration in the upper Amazonian floodplain provides between 0.7 and $115 \mathrm{Mg} \mathrm{C} \mathrm{ha}^{-1} \mathrm{yr}^{-1}$ to streamflow depending on the age of the forested floodplain areas eroded. Over the studied period and area, we found that in average $44.7 \pm 21.4$ $\mathrm{Mg} \mathrm{C} \mathrm{ha}^{-1} \mathrm{yr}^{-1}$ was delivered by lateral channel erosion to the aquatic continuum $\left(0.9 \pm 0.4 \times 10^{6}\right.$ 
MgC $\mathrm{yr}^{-1}$ delivered over $\left.19.8 \pm 6.7 \times 10^{3} \mathrm{ha}^{-1} \mathrm{yr}^{-1}\right)$. Our result is roughly equivalent to the amount

259 provided by the entire wetland system of the central Amazonian floodplain (i.e. flooded forest 260 and macrophytes litterfall and respiration; 59.6 $\pm 38.7 \mathrm{Mg} \mathrm{C} \mathrm{ha}^{-1} \mathrm{yr}^{-1}$ ), and roughly 10 times 261 higher than the amount of the woody part considered by Abril et al. (2014) i.e. $5.3 \pm 2 \mathrm{Mg} C$ $262 \mathrm{ha}^{-1} \mathrm{yr}^{-1}$.

263 The amount of $\mathrm{C}$ provided by meandering rivers is dependant on annual rates of floodplain 264 erosion. In the Amazon basin, different rates of channel migration of white-water rivers have been observed to exponentially increase from east to west (Kalliola et al., 1992; Mertes et al., 1995; Peixoto et al., 2009; Salo and Räsänen, 1989). Therefore, inputs of woody materials as a consequence of lateral channel erosion may certainly increase along a downstream-upstream gradient. Further studies are thus required to quantify the spatial variability and overall contribution of Amazonian meandering rivers. Here, we have calculated the contribution of above-ground forest biomass to streamflow, but further amounts of $\mathrm{C}$ input may originate from (i) eroded floodplain soils (i.e. belowground total organic matter; Fig. 2), and (ii) the Andean 272 mountains situated upstream the study area, where torrential streams potentially accumulate 273 and transport large amounts of coarse woody debris provided by landslides occurring in 274 particular during tropical storm events (McClain and Naiman, 2008; Clark et al., 2013; Wohl 275 and Ogden, 2013).

277 The nature of the $\mathrm{C}$ that is annually exported into the aquatic continuum is a fundamental aspect 278 when considering the fate of this $\mathrm{C}$ and its role in the global cycle. It is usually considered that 279 river $\mathrm{C}$ is advected downstream and returned to the atmosphere via degassing by both microbial 280 and photochemical activity, ultimately resulting in a net zero exchange, especially in the tropics where warm temperatures stimulate organic matter decomposition (Raymond et al., 2013; Ward 
et al., 2013). For instance, Abril et al. (2014) proposed that central Amazonian waters receive at least as much $\mathrm{C}$ from wetlands as they emit to the atmosphere, making a nearly neutral balance in atmosphere-biosphere $\mathrm{CO}_{2}$ exchanges. However, the $\mathrm{C}$ provided by meandering rivers of the upper Amazon basin most probably differs from the $\mathrm{C}$ provided by wetlands of the central Amazon. On the one hand, it has been shown for wetlands of the central Amazon that the microbial communities decompose young organic C (> 5-year-old; Mayorga et al., 2005; Abril et al., 2014). On the other hand, the organic $C$ found in the water column mainly originates from litterfall with low lignin content (Mayorga et al., 2005; Abril et al., 2014). Our results suggest that in free meandering Amazonian rivers, such as the Ucayali River, older lignin is present in substantial quantities. Higher concentrations of lignin are found in tree trunks, branches and roots of ligneous terrestrial plants, and we estimated that mature and old growth floodplain forests accounted for nearly half of the eroded floodplain area within the Ucayali 1984-2019 meander belt (Fig. 6b). However, the fate of these large C quantities of lignin remains still uncertain. One hypothesis could be that this $C$ is mineralized by microbial and photochemical activity and/or exported downstream the aquatic continuum and/or accumulated in the river sediment. Following Ward et al. (2013), half of these quantities could be degraded and mineralized in the Amazon River. Anyhow, according to Galy et al. (2015), the erosion and transportation capacities of rivers are to be considered as the main control of the biospheric C export to oceans. Many large water storage reservoirs have been recently proposed for the Amazon Basin (Finer and Jenkins, 2012). Since meandering rivers are known to be highly sensitive to the disruption of sediment supply caused by such engineering projects (Constantine et al, 2014), it is highly suspected that such human infrastructures will greatly alter the natural C fluxes we have here quantified.

\section{Conclusion}


Although the area of the Ucayali’s 1984-2019 meander belt represents only a small fraction of the Amazonian basin area, it significantly contributes to the amount of $\mathrm{C}$ that is transferred from the floodplain forest to the aquatic continuum. The amount of woody $\mathrm{C}$ per unit area provided

309 by floodplain erosion caused by lateral channel erosion is nearly ten-fold higher than that 310 provided by central Amazon wetlands. Extrapolation of our results suggests that free 311 meandering white-water rivers may act as major agent in the global C cycle. These findings 312 point to the importance to quantify the overall contribution of free meandering forested 313 floodplain rivers worldwide to the global C cycle. In addition to variations in channel migration 314 rates, different floodplain tree species may show contrasting C-stock potentials and related 315 forest carbon export rates according to climate zones and biogeographical regions.

\section{Author contributions}

317 Romain Wacker: Conceptualization, Methodology, Formal analysis, Writing- Original draft 318 preparation. Dov Corenblit: Original Idea, Supervision, Conceptualization, Writing- Original 319 draft preparation. Frédéric Julien: Writing - Review \& Editing. Jean-Michel Martinez: 320 Writing - Review \& Editing. Johannes Steiger: Writing - Review \& Editing.

\section{Competing interest statement}

322 The authors have no competing interests to declare.

\section{Acknowledgements}

324 RW acknowledges financial support from the French National Research Agency through an 325 Investissement d’Avenir (Labex CEBA, ref. ANR-10-LABX-25-01).

\section{References}


Abril, G., Martinez, J.-M., Artigas, L. F., Moreira-Turcq, P., Benedetti, M. F., Vidal, L., Meziane, T., Kim, J.-H., Bernardes, M. C., Savoye, N., Deborde, J., Souza, E. L., Albéric, P., Landim de Souza, M. F., \& Roland, F. (2014). Amazon River carbon dioxide outgassing fuelled by wetlands. Nature 505, 395-398. https://doi.org/10.1038/nature12797

Allen, J.R.L. (1965) A review of the origin and characteristics of recent alluvial sediments. Sedimentology 5, 89-191.

Clark, K. E., Hilton, R. G., West, A. J., Malhi, Y., Gröcke, D. R., Bryant, C. L., Ascough, P. L., Robles Caceres, A., \& New, M. (2013). New views on "old" carbon in the Amazon River: Insight from the source of organic carbon eroded from the Peruvian Andes. Geochemistry, Geophysics, Geosystems 14, 1644-1659. https://doi.org/10.1002/ggge.20122

Constantine, J. A., Dunne, T., Ahmed, J., Legleiter, C., \& Lazarus, E. D. (2014). Sediment supply as a driver of river meandering and floodplain evolution in the Amazon Basin. Nature Geoscience 7, 899-903. https://doi.org/10.1038/ngeo2282

Drake, T. W., Raymond, P. A., Spencer, R. G. M. (2018) Terrestrial carbon inputs to inland waters: A current synthesis of estimates and uncertainty. Limnology and Oceanography Letters 3, 123-142. https:// doi.org/10.1002/lol2.10055

Feng, X., Feakins, S. J., Liu, Z., Ponton, C., Wang, R. Z., Karkabi, E., Galy, V., Berelson, W. M., Nottingham, A. T., Meir, P., \& West, A. J. (2016). Source to sink: Evolution of lignin composition in the Madre de Dios River system with connection to the Amazon basin and offshore. Journal of Geophysical Research : Biogeosciences 121, 1316-1338. https://doi.org/10.1002/2016JG003323

Filoso, S., Williams, M. R., \& Melack, J. M. (1999). Composition and deposition of throughfall in a flooded forest archipelago. Biogeochemistry 45, 169-195. https://doi.org/10.1023/A:1006108618196

Finer M, Jenkins CN (2012) Proliferation of Hydroelectric Dams in the Andean Amazon and Implications for Andes-Amazon Connectivity. PLoS ONE 7(4): e35126. https://doi.org/10.1371/journal.pone.0035126

Galy, V., Peucker-Ehrenbrink, B., \& Eglinton, T. (2015). Global carbon export from the terrestrial biosphere controlled by erosion. Nature 521, 204-207. https://doi.org/10.1038/nature14400

Gorelick, N., Hancher, M., Dixon, M., Ilyushchenko, S., Thau, D., \& Moore, R. (2017). Google Earth Engine: Planetary-scale geospatial analysis for everyone. Remote Sensing of Environment 202, 18-27. https://doi.org/10.1016/j.rse.2017.06.031

Hoffmann, T., Glatzel, S., \& Dikau, R. (2009). A carbon storage perspective on alluvial sediment storage in the Rhine catchment. Geomorphology, 108, 127-137. https://doi.org/10.1016/j.geomorph.2007.11.015

HYBAM, www.sno-hybam.org, last access at 01/12/2020.

Junk, W. J. (1985). The Amazon floodplain-a sink or source for organic carbon. Mitteilungen aus dem Geologische-Palaontologischen Institut der Universitat Hamburg. SCOPE/UNEP Sonderband 58, 267-283.

Junk, Wolfgang J., Bayley, Peter B., Sparks, R. (1989). The flood pulse concept in riverfloodplain systems. In Canadian Journal of Fisheries and Aquatic Science, 106, 10 127.

Kalliola, R., Salo, J., Puhakka, M., \& Rajasilta, M. (1991). New Site Formation and Colonizing Vegetation in Primary Succession on the Western Amazon Floodplains. The Journal of Ecology 79, 877-901. https://doi.org/10.2307/2261087

Kalliola, R., Salo, J., Puhakka, M., Rajasilta, M., Häme, T., Neller, R.J., E. Räsänen M.E., \& Danjoy Aria, W.A. (1992) Upper Amazon channel migration: implications for 
vegetation disturbance and succession using bitemporal Landsat MSS images. Naturwissenschaften 79, 75-79.

Lamotte, S. (1990). Fluvial dynamics and succession in the Lower Ucayali River basin, Peruvian Amazonia. Forest Ecology and Management 33, 141-156.

Ielpi, A., Lapôtre, M. G. A. (2019) A tenfold slowdown in river meander migration driven by plant life. Nature Geoscience 13, 82-86. https://doi.org/10.1038/s41561-019-0491-7

Leopold, L.B. \& Wolman, M.G. (1960) River meanders. Geologicla Society of America Bulletin 71, 769-794.

Mayorga, E., Aufdenkampe, A. K., Masiello, C. A., Krusche, A. V., Hedges, J. I., Quay, P. D., Richey, J. E., \& Brown, T. A. (2005). Young organic matter as a source of carbon dioxide outgassing from Amazonian rivers. Nature 436, 538-541. https://doi.org/10.1038/nature03880

McClain, M. E., \& Naiman, R. J. (2008). Andean influences on the biogeochemistry and ecology of the Amazon River. BioScience 58, 325-338. https://doi.org/10.1641/B580408

Mertes, L. A. K., Daniel, D. L., Melack, J. M., Nelson, B., Martinelli, L. A., \& Forsberg, B. R. (1995). Spatial patterns of hydrology, geomorphology, and vegetation on the floodplain of the Amazon river in Brazil from a remote sensing perspective. Geomorphology 13, 215-232 https://doi.org/10.1016/0169-555X(95)00038-7

Neu, V., Ward, N. D., Krusche, A. V., \& Neill, C. (2016). Dissolved organic and inorganic carbon flow paths in an amazonian transitional forest. Frontiers in Marine Science 3 https://doi.org/10.3389/fmars.2016.00114

Peixoto, J. M. A., Nelson, B. W., Wittmann, F. (2009) Spatial and temporal dynamics of river channel migration and vegetation in centralAmazonian white-water floodplains by remote-sensing techniques. Remote Sensing of Environment 113, 2258-2266. http://dx.doi.org/10.1016/j.rse.2009.06.015

Pekel, J. F., Cottam, A., Gorelick, N., \& Belward, A. S. (2016). High-resolution mapping of global surface water and its long-term changes. Nature 540, 418-422. https://doi.org/10.1038/nature20584

Puhakka, M., Kalliola, R., Rajasilta, M., \& Salo, J. (1992). River Types, Site Evolution and Successional Vegetation Patterns in Peruvian Amazonia. Journal of Biogeography. https://doi.org/10.2307/2845707

Raymond, P. A., Hartmann, J., Lauerwald, R., Sobek, S., McDonald, C., Hoover, M., Butman, D., Striegl, R., Mayorga, E., Humborg, C., Kortelainen, P., Dürr, H., Meybeck, M., Ciais, P., \& Guth, P. (2013). Global carbon dioxide emissions from inland waters. Nature 503, 355-359. https://doi.org/10.1038/nature12760

Richey, J. E., Brock, J. T., Naiman, R. J., Wissmar, R. C., \& Stallard, R. F. (1980). Organic carbon: oxidation and transport in the Amazon River. Science 207, 1348-1351. https://doi.org/10.1126/science.207.4437.1348

Salo, J., Kalliola, R., Häkkinen, I., Mäkinen, Y., Niemelä, P., Puhakka, M., \& Coley, P. D. (1986). River dynamics and the diversity of Amazon lowland forest. Nature 322, 254258. https://doi.org/10.1038/322254a0

Salo, J., \& Räsänen, M. (1989). Hierarchy of landscape patterns in western Amazon. In: HolmNielsen, L.B., Nielsen, I.C., Balslev, H. (eds) Tropical forests: Botanical dynamics, speciation and diversity, Academic Press, London.

Santini, W., Camenen, B., Le Coz, J., Vauchel, P., Guyot, J. L., Lavado, W., Villar, R. E., Julien F. \& Martinez J.M. (2019). An index concentration method for suspended load monitoring in large rivers of the Amazonian foreland. Earth Surface Dynamics 7, 515536. https://doi.org/10.5194/esurf-7-515-2019 
Sawakuchi, H. O., Neu, V., Ward, N. D., Barros, M. de L. C., Valerio, A. M., Gagne-Maynard, W., Cunha, A. C., Less, D. F. S., Diniz, J. E. M., Brito, D. C., Krusche, A. V., \& Richey, J. E. (2017). Carbon dioxide emissions along the lower Amazon River. Frontiers in Marine Science 4. https://doi.org/10.3389/fmars.2017.00076

Schöngart J., Wittmann F. (2010) Biomass and Net Primary Production of Central Amazonian Floodplain Forests. In: Junk W., Piedade M., Wittmann F., Schöngart J., Parolin P. (eds) Amazonian Floodplain Forests. Ecological Studies (Analysis and Synthesis), vol 210. Springer, Dordrecht. https://doi.org/10.1007/978-90-481-8725-6_18

Schwenk, J., Khandelwal, A., Fratkin, M., Kumar, V., \& Foufoula-Georgiou, E. (2017). High spatiotemporal resolution of river planform dynamics from landsat: The rivMAP toolbox and results from the Ucayali river. Earth and Space Science 4, 46-75. https://doi.org/10.1002/2016EA000196

Spencer, R. G. M., Aiken, G. R., Dornblaser, M. M., Butler, K. D., Holmes, R. M., Fiske, G., Mann, P. J., Stubbins, A. (2013) Chromophoric dissolved organic matter export from US rivers. Geophysical Research Letters 40, 1575-1579. https://doi.org/10.1002/grl.50357

Sutfin, N. A., Wohl, E. E., \& Dwire, K. A. (2016). Banking carbon: A review of organic carbon storage and physical factors influencing retention in floodplains and riparian ecosystems. Earth Surface Processes and Landforms 41, 38-60. https://doi.org/10.1002/esp.3857

Torres, M. A., Limaye, A. B., Ganti, V., Lamb, M. P., West, A. J., Fischer, W. W. (2017) Model predictions of long-lived storage of organiccarbon in river deposits. Earth Surface Dynamics 5, 711-730. https://doi.org/10.5194/esurf-5-711-2017

Ward, N. D., Bianchi, T. S., Medeiros, P. M., Seidel, M., Richey, J. E., Keil, R. G., \& Sawakuchi, H. O. (2017). Where Carbon Goes When Water Flows: Carbon Cycling across the Aquatic Continuum. Frontiers in Marine Science 4. https://doi.org/10.3389/fmars.2017.00007

Ward, N. D., Keil, R. G., Medeiros, P. M., Brito, D. C., Cunha, A. C., Dittmar, T., Yager, P. L., Krusche, A. V., \& Richey, J. E. (2013). Degradation of terrestrially derived macromolecules in the Amazon River. Nature Geoscience 6,530-533. https://doi.org/10.1038/ngeo1817

Wohl, E., \& Ogden, F. L. (2013). Organic carbon export in the form of wood during an extreme tropical storm, Upper Rio Chagres, Panama. Earth Surface Processes and Landforms, 38, 1407-1416. https://doi.org/10.1002/esp.3389

Wohl, E., Dwire, K., Sutfin, N., Polvi, L., \& Bazan, R. (2012). Mechanisms of carbon storage in mountainous headwater rivers. Nature communications 3, 1-8. 
464

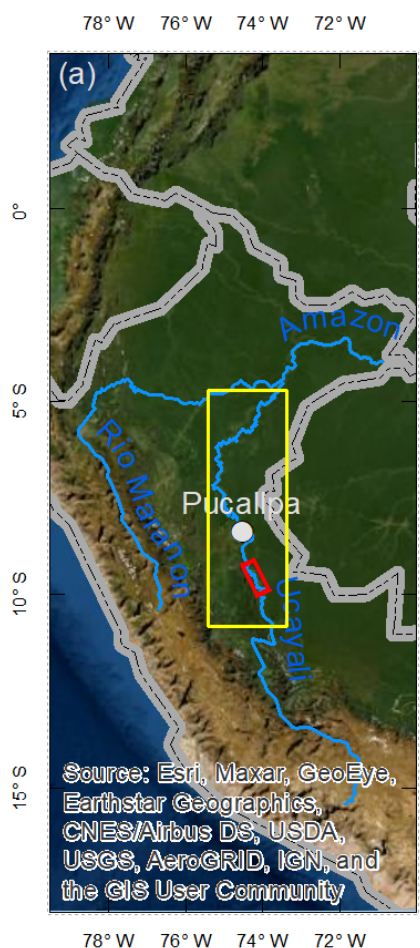

$9.17^{\circ} \mathrm{S} 74.17^{\circ} \mathrm{W} \quad 9.33^{\circ} \mathrm{S}$

$9.5^{\circ} \mathrm{S} \quad 74^{\circ} \mathrm{W}$

$9.67^{\circ} \mathrm{S}$

$9.83^{\circ} \mathrm{S}$
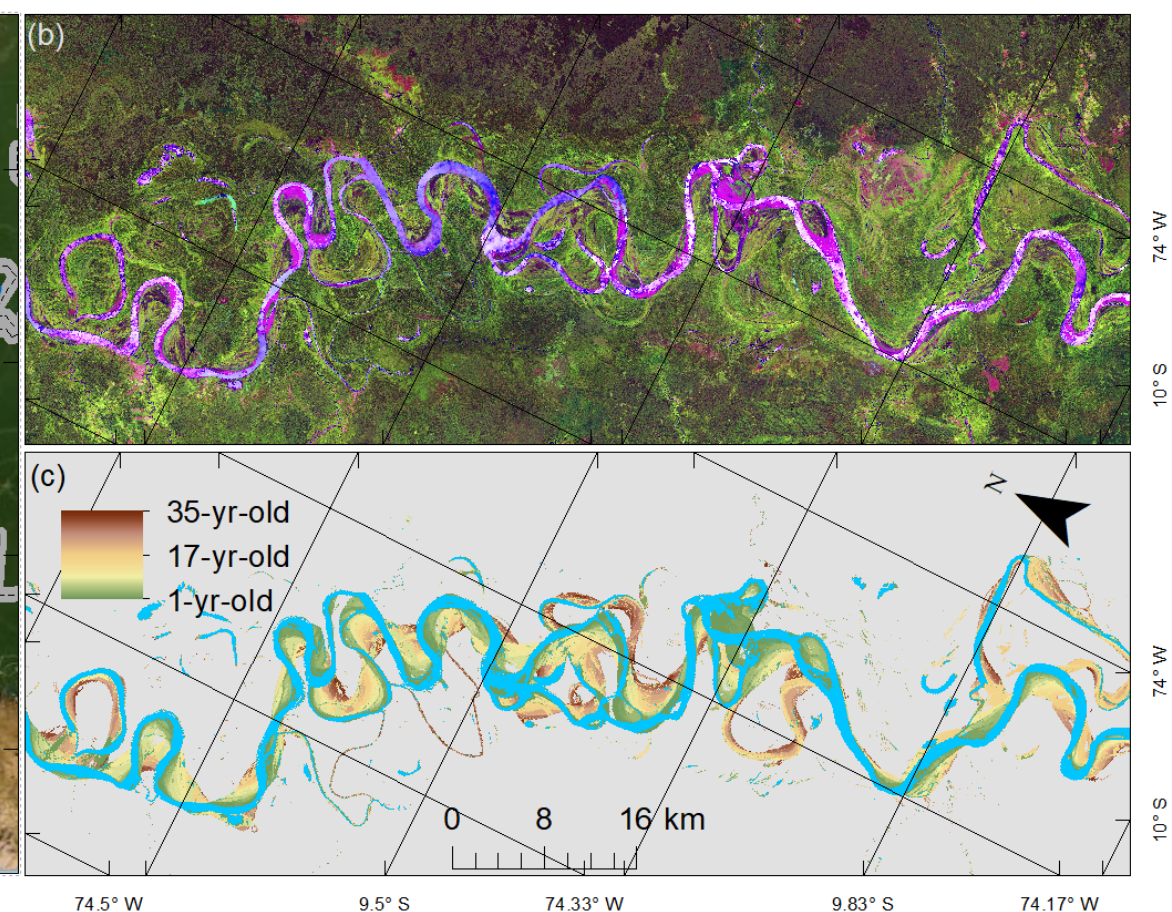

Figure 1 The freely meandering Ucayali River in the upper Amazonian region, Peru. (a) Location map: the yellow rectangle indicates the extent of the study area and the red rectangle indicates the extensions of panels (b) and (c), located approximately $120 \mathrm{~km}$ upstream of Pucallpa, Peru. (b) False colour composite satellite image showing the Ucayali meander belt extension in light green. This cloud-free satellite Landsat 8 image was obtained through the selection of the greenest pixels over the year 2018. The first short wave infra-red satellite band was affected to the red colour on screen, the near infra-red band to the green and the red band to the blue. (c) Floodplain ages range from 1-year (green colour) to 35-year (brown colour) within the 1984-2019 meander belt. Blue and grey colours correspond respectively to surface water and upland areas formed before 1984 (non-determined ages), respectively. 


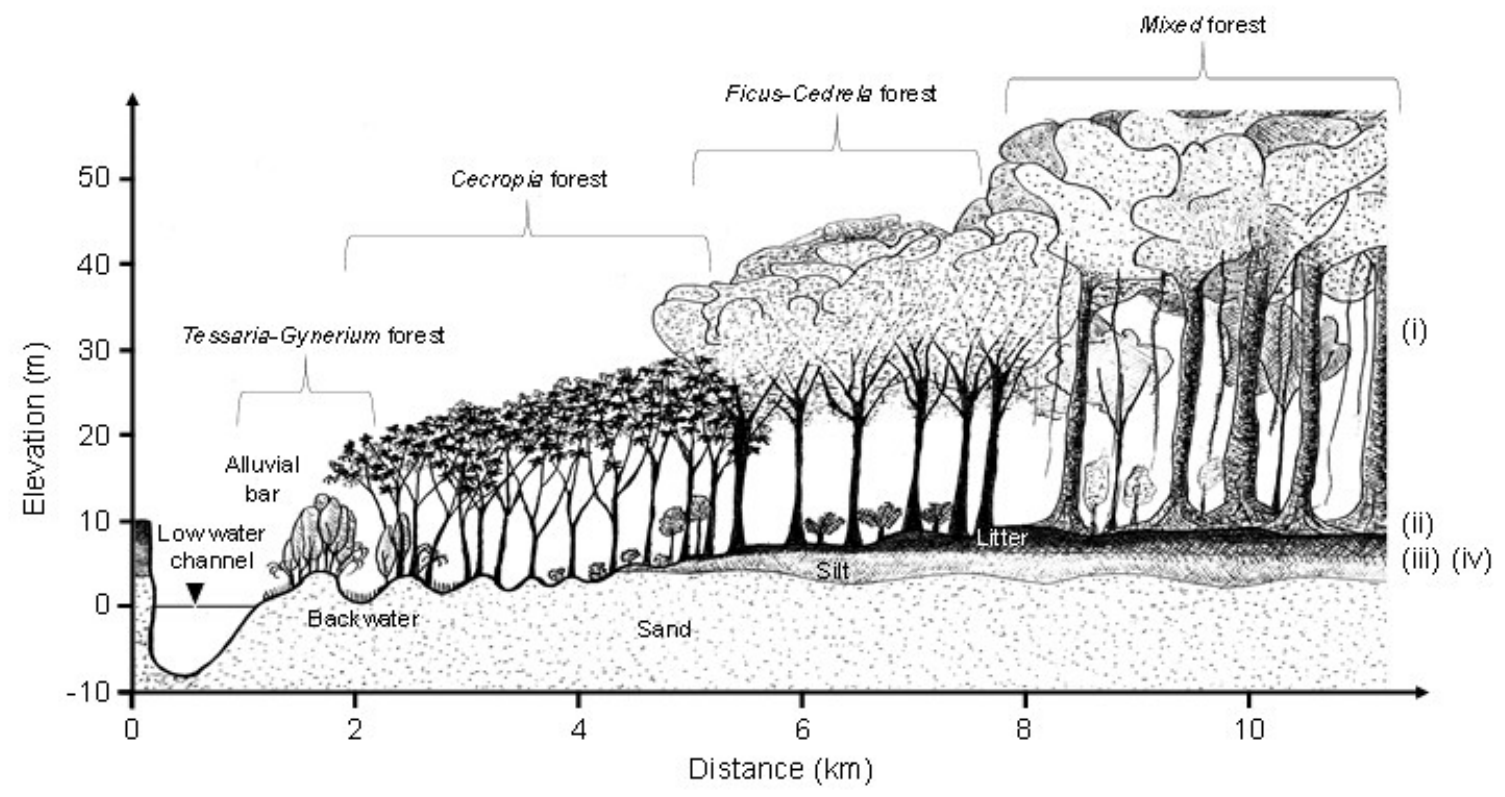

478 Figure 2 Simplified model of the floodplain vegetation succession in the study area which 479 comprises four main interrelated carbon reservoirs (modified from Salo et al., 1986; Kayranli 480 et al., 2010; Stufin et al., 2016): (i) aboveground living terrestrial and seasonally flooded forest 481 biomass (trunk, branches and foliage); (ii) aboveground necromass (dead wood and litter); (iii) 482 belowground living biomass (roots and micro-organisms); and (iv) total organic matter in the soil (decomposed dead organic flora and fauna). The present study focused on the first carbon reservoir of the floodplain, i.e. aboveground living terrestrial and seasonally flooded forest biomass. 


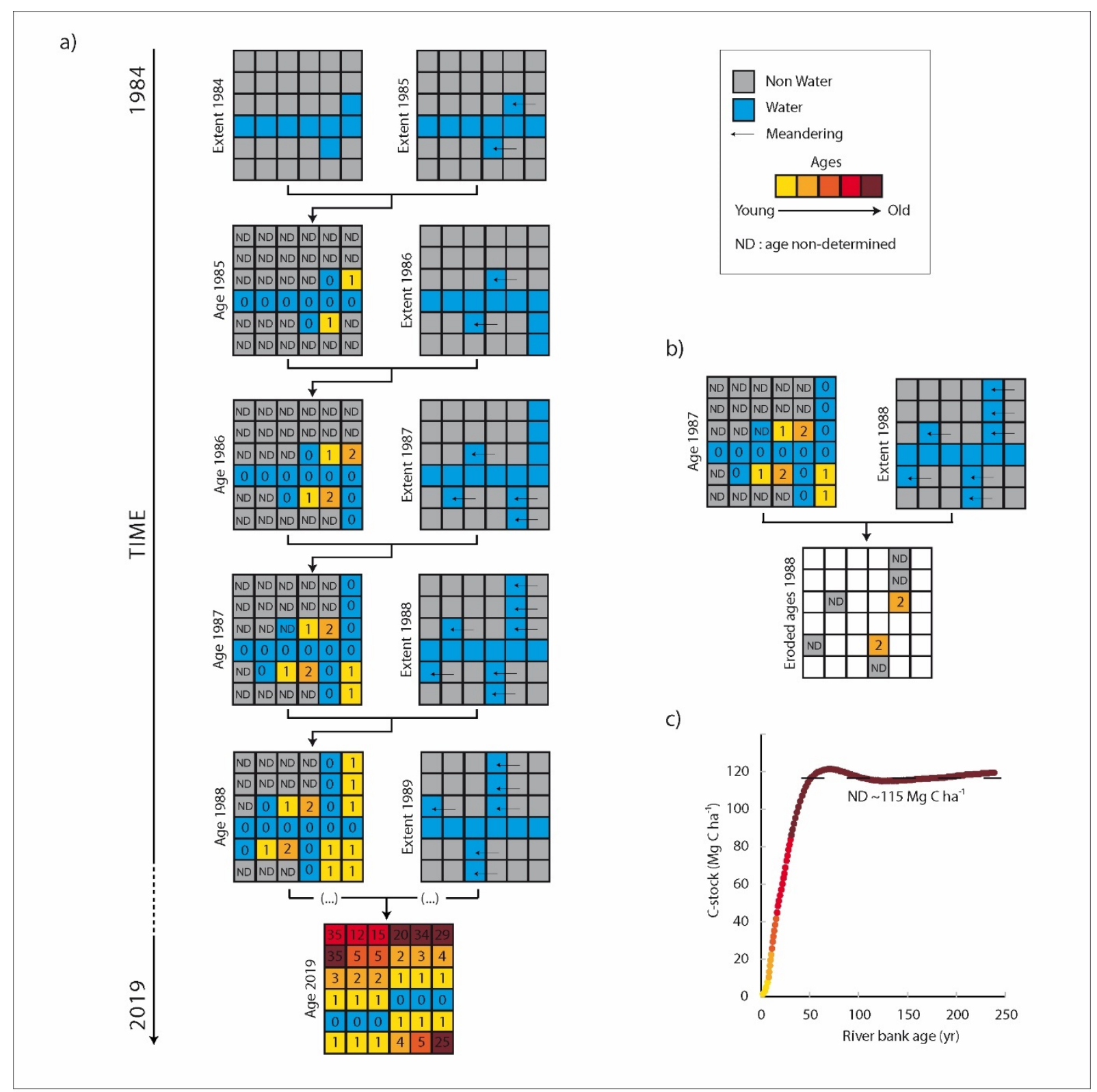

489 Figure 3 Conceptual approach used to derive forest above ground carbon stock (C-stock) from 490 floodplain area age. a) Pixel-by-pixel and year-by-year algorithm used to obtain yearly maps 491 of area ages based on the analysis of the yearly water classification history dataset (Pekel et al., 492 2016). b) Pixel-by-pixel and year-by-year algorithm used to obtain yearly maps of eroded 493 floodplain area ages. c) Data series used to model and derive C-stocks from floodplain area 494 495 ages (Schöngart and Wittmann, 2010). 


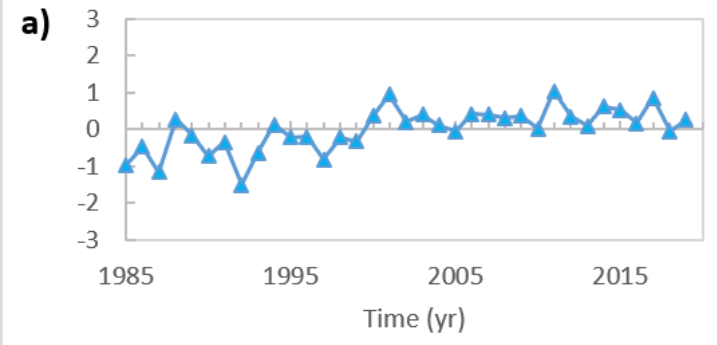

b)
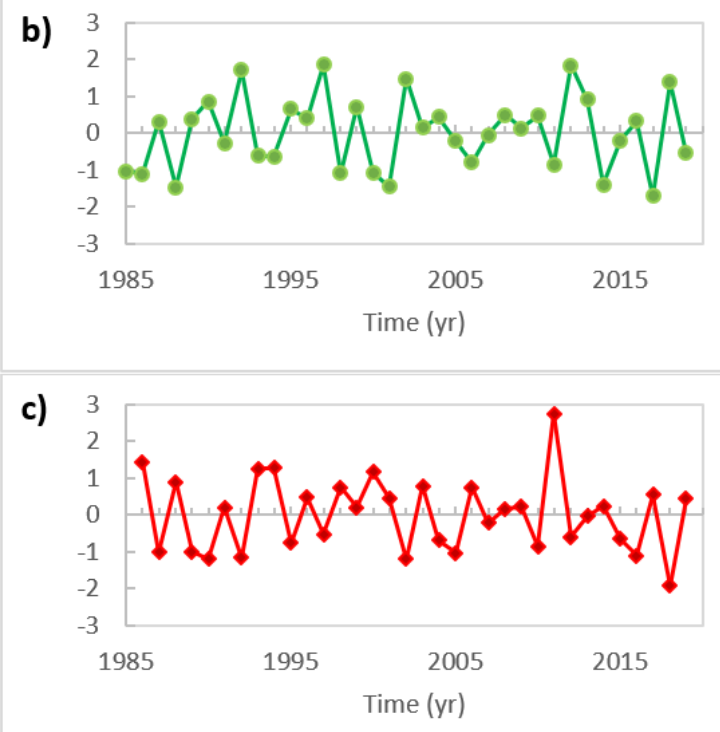

497 Figure 4 Annual area fluctuations of a) water surfaces, b) floodplain formation and c) 498 floodplain erosion between 1984 and 2019. Values are standardized, i.e. the 1984-2019 average 499 was subtracted and the result was divided by the 1984-2019 standard deviation. 


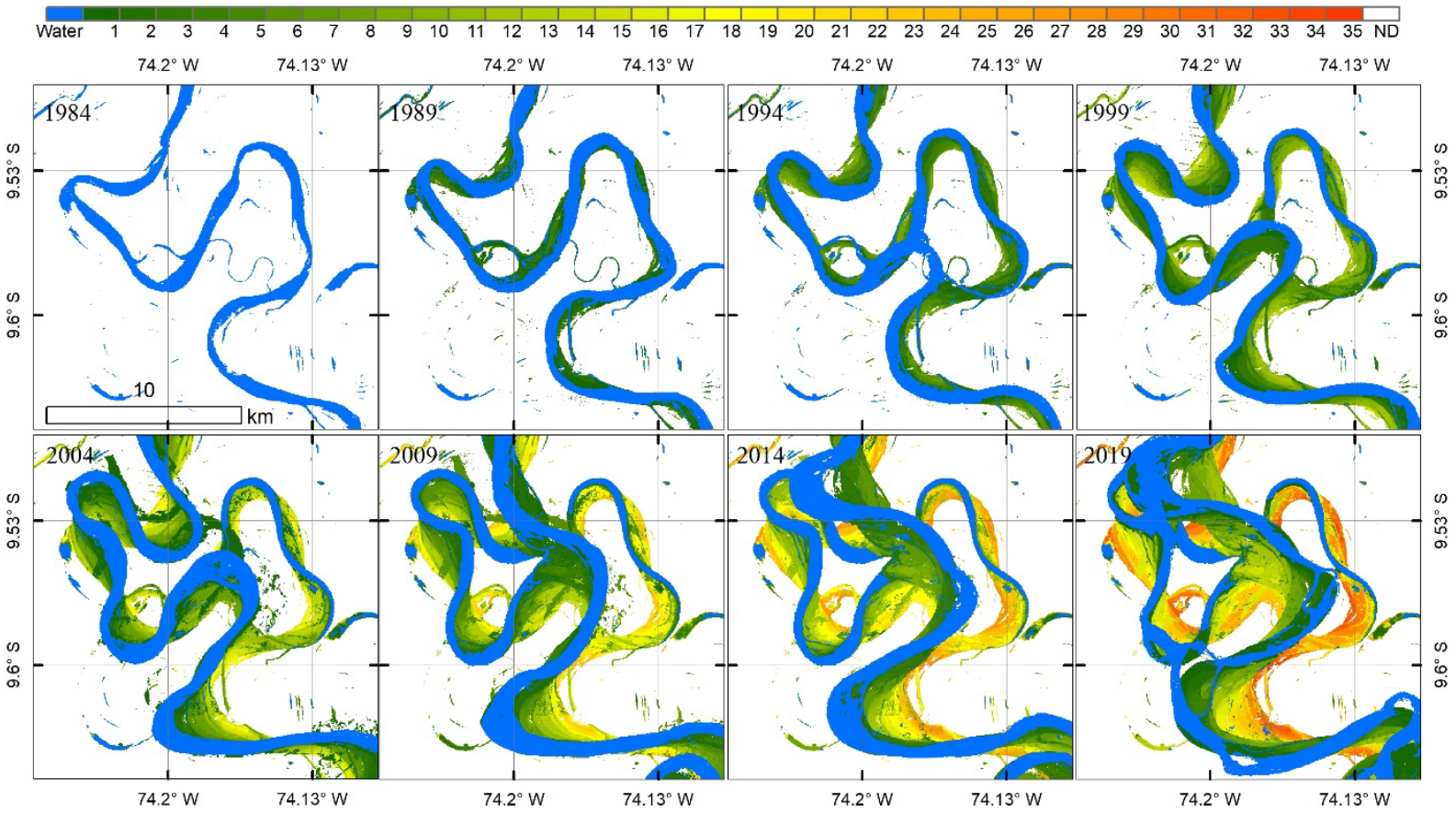

Figure 5 River meandering and floodplain forest dynamics according to a 5-yr time interval between 1984 and 2019 in the vicinity of Sampaya (Peru). Annual maps were created using the algorithm described in Fig. 3a. Non-eroded, remaining floodplain and upland forests which established before 1984 are indicated as age non-determined (ND; white colour). 

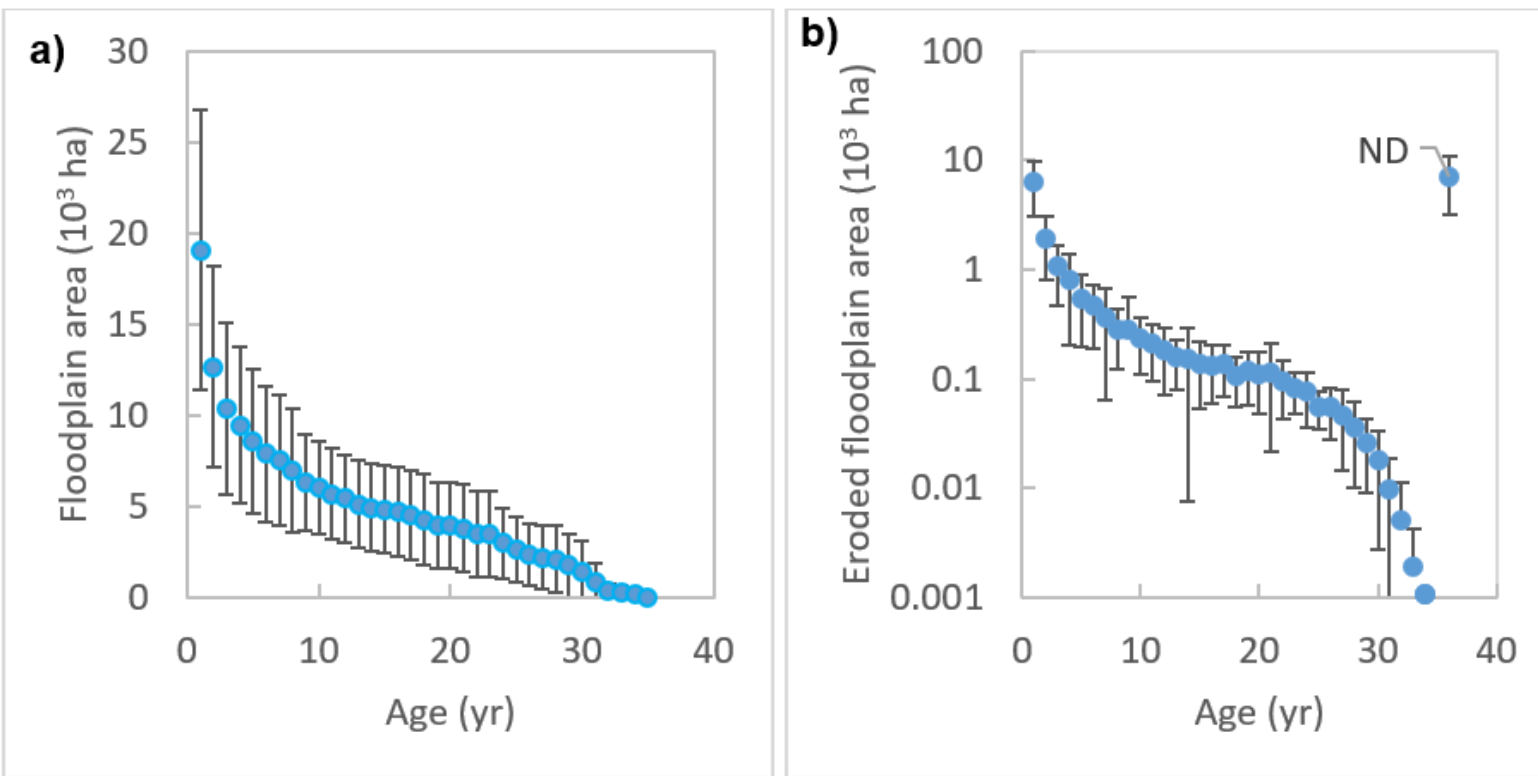

509 Figure 6 Age structure of vegetated floodplain areas observed in the 1984-2019 active meander 510 belt. a) Floodplain areas according to floodplain ages established since 1984. b) Eroded 511 floodplain areas since 1984 according to floodplain ages. Non-determined ages (ND) 512 corresponding to floodplain or upland areas established before 1984, were considered for 513 erosion. Together, mean annual erosion accounted for $19.8 \pm 6.7 \times 10^{3} \mathrm{ha}^{-1} \mathrm{yr}^{-1}$. Points and bars 514 indicate annual mean values for the period 1984-2019 and their standard deviations, 515 respectively. 


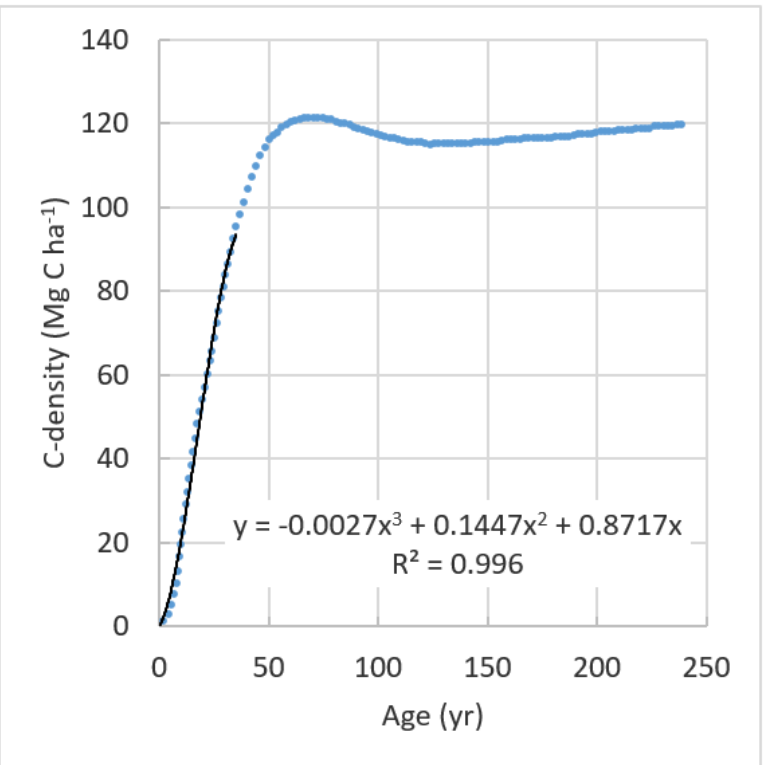

518 Figure 7 Model used to derive above-ground forest C-stocks from floodplain forest age. The model between 1 and 35 years (3rd polynomial; black line) is based on data (dots) published by Schöngart and Wittman (2010). The data error range is $\pm 2 \%$ (not indicated in the figure). 


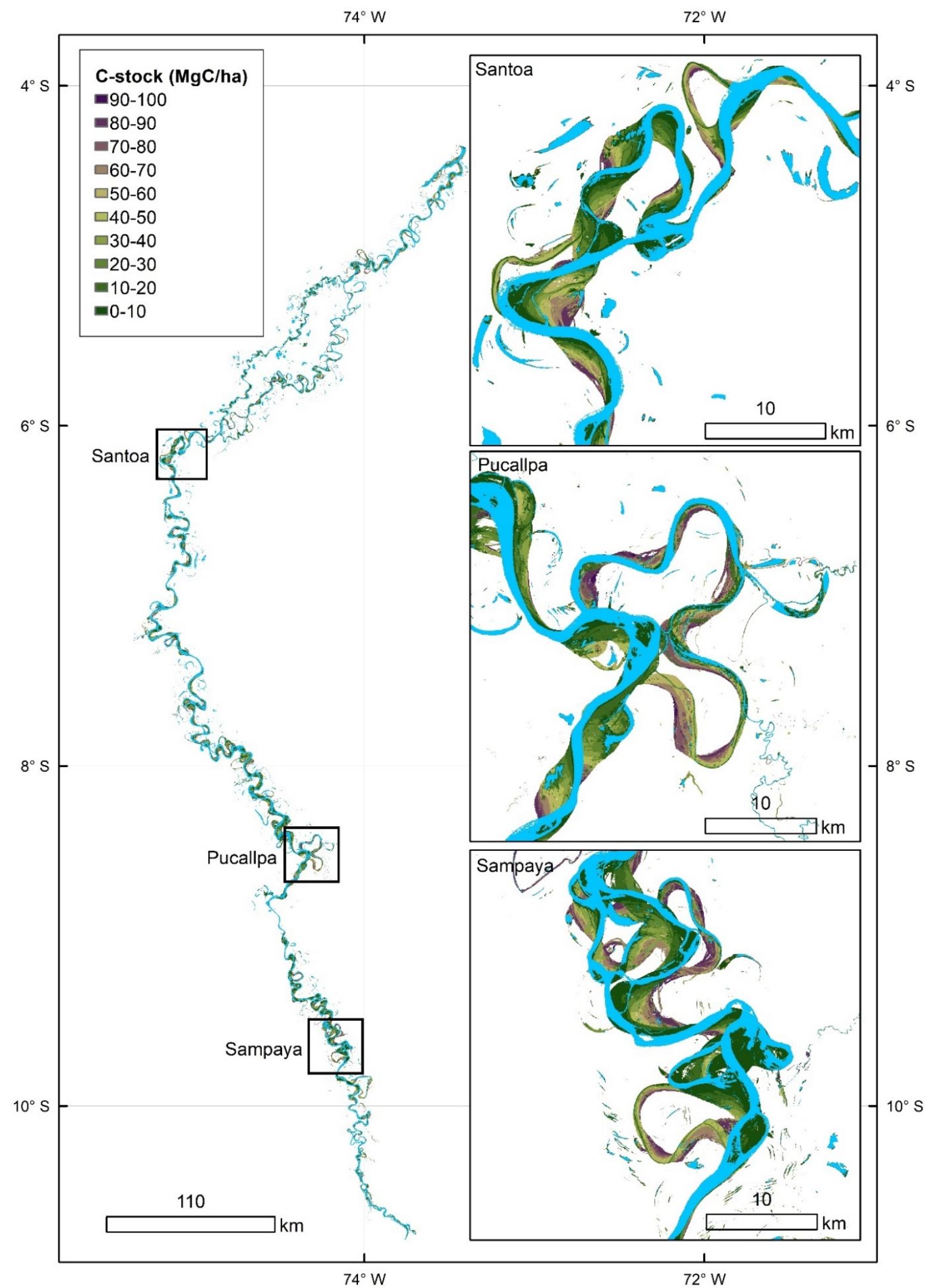

Figure 8 Above-ground floodplain forest carbon stock (C-stock in $\mathrm{Mg} \mathrm{C} \mathrm{ha}{ }^{-1}$ ) in the Ucayali 1984-2019 meander belt. Thirty yearly maps were produced for the 1984-2019 period. This figure shows the map of 2019. 

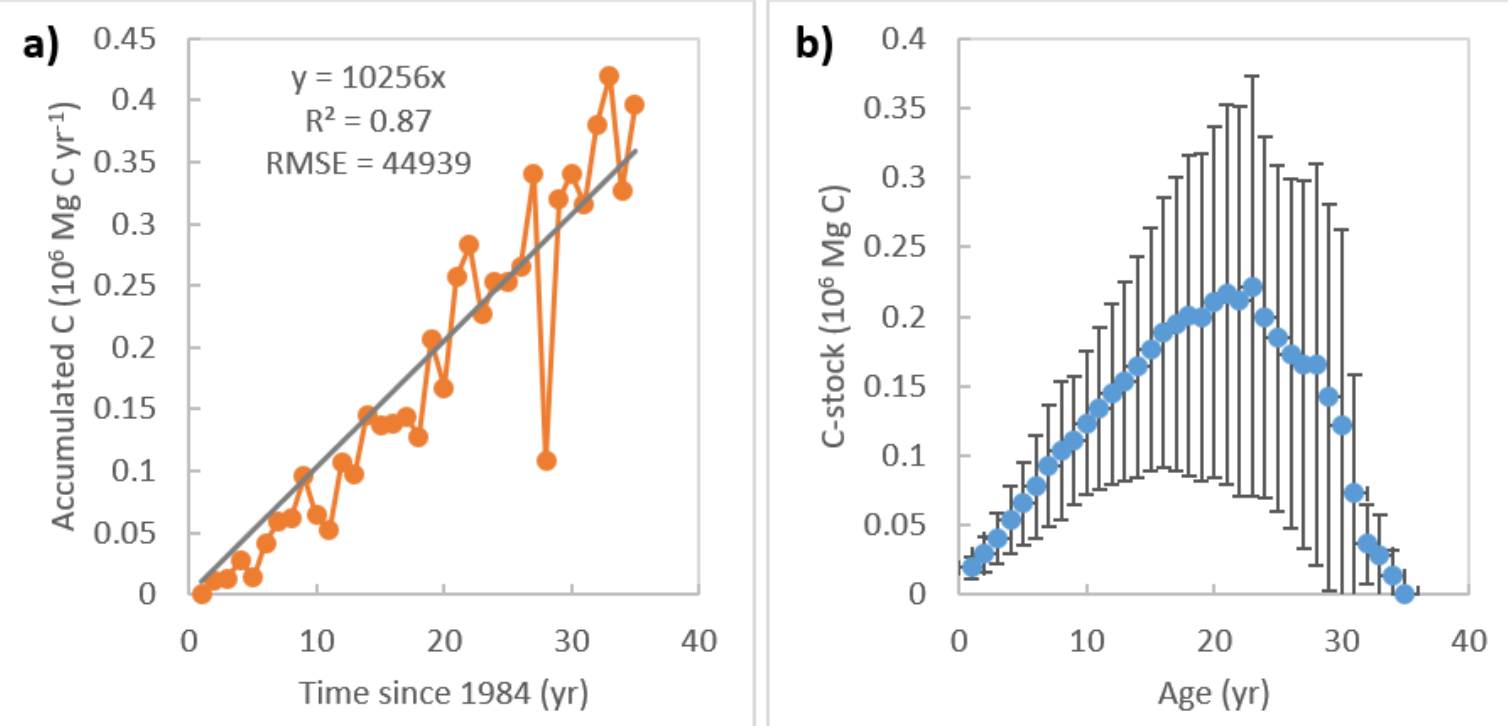

Figure 9 Floodplain forest carbon stocks (C-stocks) during the 1984-2019 period in the Ucayali active meander belt. a) Annual C accumulation in the floodplain forest established since 1984 and quantified annually until 2019. The black line indicates the annual $\mathrm{C}$ accumulation rate as

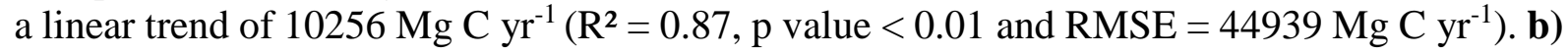
Annual C-stock accumulated in the floodplain forest according to the floodplain age established since 1984. 

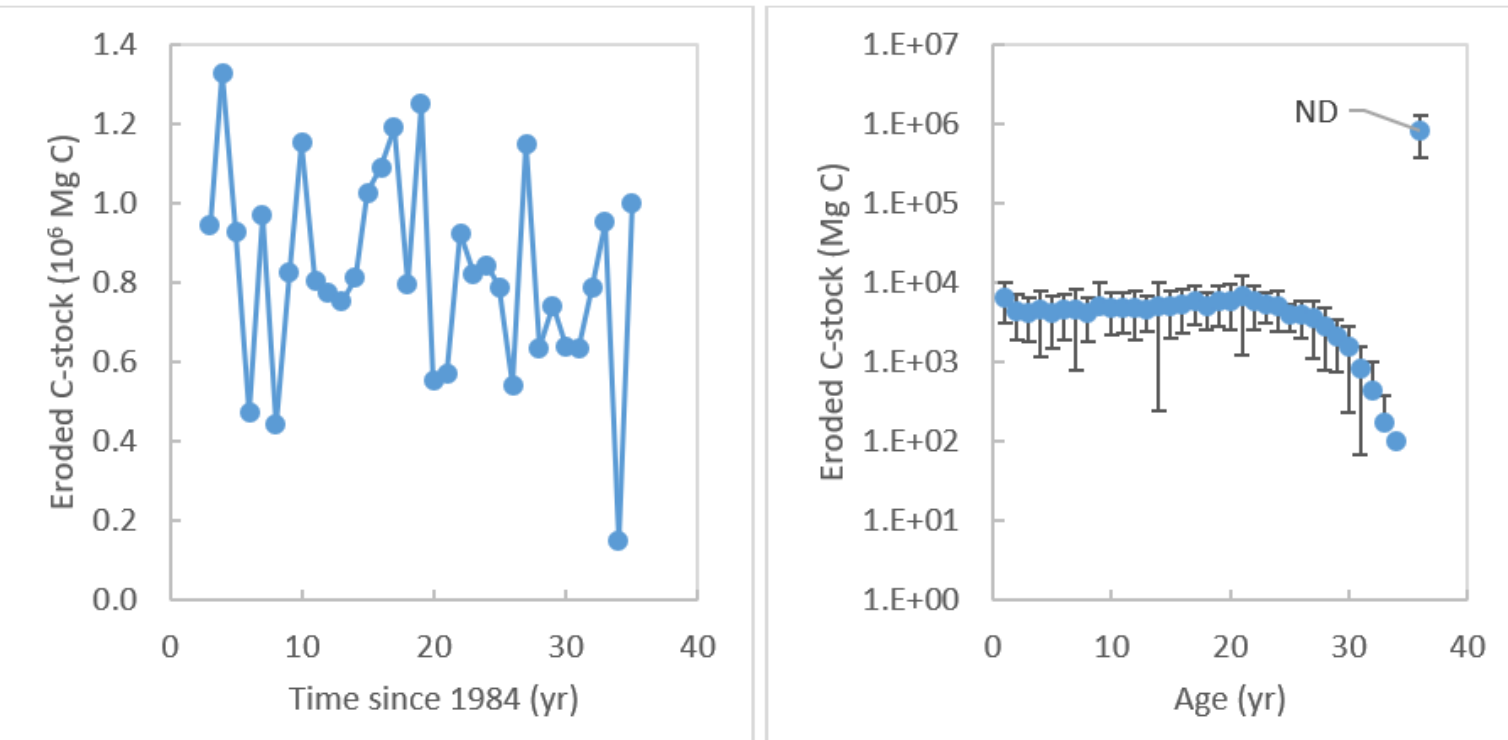

539 Figure 10 Erosion of floodplain forest carbon stocks (C-stocks) caused by lateral channel 540 migration. a) Annual C-stocks eroded from the floodplain forest during lateral channel 541 migration between 1984 and 2019. b) Annual C-stock eroded from the floodplain forest during 542 lateral channel migration according to forest age. ND indicates floodplain and upland forests established before 1984 . 